\title{
Social Mix, A Living Together Through Public Space: Case Study
}

\author{
Afri Amira \\ Doctorante, Laboratoire de l'Architecture à l'Urbanisme Technique, \\ Espace et Société (LAUTES), Faculté D'architecture et d'Urbanisme, \\ Université Constantine 3, Algeria \\ Benrachi Bouba \\ Professeur, Laboratoire de l'Architecture à l'Urbanisme Technique, \\ Espace et Société (LAUTES), Faculté d'Architecture et d'Urbanisme, \\ Université Constantine 3, Algeria
}

DOI: https://doi.org/10.36941/ajis-2022-0022

\begin{abstract}
This article proposes the study of social mix evolution of through the public space. To that end, attention is focused on the "Frères Fisli" neighbourhood in Azzaba city as a case study. A social space, which, is considered as an adequate place, that promotes social mix and living together between Algerian inhabitants of different types of habitat that exist. The main objective of this article is to quantify the impact of public spaces to achieve the goal of social mix and its management, in order to promote living together. In order to carry out our survey, the study uses two survey tools: the mind map and the questionnaire. The choice of these two tools is not fortuitous. It has been studied in order to carefully check whether the constraints for the public space development are dependent on the evolution of inhabitants 'social relations.
\end{abstract}

Keywords: social mix, living together, Public space, Mind Map, questionnaire

\section{Introduction}

The city is a historical spatial production of successive periods, where the expression of social, economic and religious practices intertwines. It is in this space, which is both built and inbuilt, that social interactions and relationships between residents take place. As a result, living together of inhabitants and the relationships that develop through the various activities offered by public spaces can bring together as many people to meet, have fun, play together, walk, rest, etc. To this end, these spaces bringing together several people of different ages, genders and social categories or classes, play a crucial role in people's lives, allowing them to escape everyday problems in a moment. In particular, these spaces optimize living together by this social mix.

According to Baudin (2001) "In an operational fashion, mixing would be defined as the characteristic of a mixture of heterogeneous or different elements. This definition would lead to consider social mix as the co-presence or cohabitation in the same place of people or groups that are different socially, culturally or even of different nationalities. Therefore, intervention on the social 
side is very important and its consideration in social mix policies must be examined. In this area, we are most often faced with practices that dissociate social, built and economic (Costarelli \& all, 2019).

However, the concept of social mix does not have a single and simple definition. Several research works have been carried out in recent years. From this work, it is possible to identify several advances relating to social mix that make it an aspect, which needs to be defined (Hirtt \& Delvaux, 2017; Elves, 2019; Hautière, 2011; Lelevrier, 2008). Among the most absolute definition is that of Lelevrier, (Lelevier, 2008) who considers the social mix as a mean that allows a living environment to evolve as a place of exchange between inhabitants of different origins and different standards of living, while putting available to them the living and housing conditions that promote social cohesion between them with security. In fact, well before, it is an expression of public action, whose use is relatively recent even if the idea is old, in particular in the field of housing and city policies (Lelevrier, 2016).

However, this concept of social mix presents an important field of research linked to urban development and life within neighbourhoods (Baudin, 2001). It serves as a reflection basis for the development and implementation of a comprehensive approach for the enhancement of existing residential areas (Kerivel \& James, 2019). Indeed, social mix is considered as a necessary vector for life, which allows contribution between citizens, and limits social cleavage and tensions (Belmessous, 2013). Its objective is to inhabit the city or the neighbourhood in a social intermingling between inhabitants with a social diversity and different social characteristics, in the same so-called public space (Hristova \& all, 2016).

Public space is a meeting place, a place to welcome collective expressions. This means opportunities for social bonding, well-being, but also ill-being (conflicts of use, noise and visual pollution, poor planning, etc.) (Nowicka \& Vertovec; 2014). This is why, the articulation of different needs according to audiences and a reflection on the spatial, temporal and sensory components is necessary (Vacon, Rivard \& al, 2015).

This space is an essential mean for social interaction in order to open up, to understand others, and to be into conversations with them (Bourdin \& Cornier, 2017). Thus, it is seen as the guarantor of life and social integration quality, because its organization structures social relations (Voisin Bormuth, 2019). Likewise, the quality of its development is singular from an economic point of view according to various observations (Monnet, 2012). In addition, the multiplication of its frequentation can serve the economic activities already present and / or generate new activities, to achieve social diversity (Voisin Bormuth, 2019).

Therefore, the perception of public spaces represents the lived experiences of inhabitant who uses it. The latter constantly constructs images of the spaces in which he lives by relying on the mental evocation of the real that surrounds him (Mole \& Rohmer, 1972). Thus, the perception of space is not the concrete spatial reality, but it is necessary for its apprehension: it is a cognitive act, making it possible to achieve knowledge and understanding, even to the exploitation of the world. On the other hand, perception relies on what is real, the exterior and the environment, to interpret it and generate an image (Champagne, 2005).

\section{Problem Statement}

Among other Maghreb cities, Algerian cities represent cases where social mix is not a real subject of study, which is hardly considered within public policies. This notion is not planned or programmed into the spatial design of cities or neighbourhoods. However, in this context of housing crisis and the continued mass construction of housing, the question would be relevant, because it is an essential element in the development of city dynamics.

Living together in the small town of Azzaba is determined by a set of characteristics linked to the way of life of inhabitants, its culture, its traditions, etc., and also by the structural elements that make up the city (public space, housing, etc.), in which inhabitant shares his life with his neighbours.

A reading of Azzaba city, allocated to Skikda "Wilaya", necessarily leads to the transcription of 
its mostly residential built space. The latter constitutes the first translation of any social stabilization with all that its surrounding built context can offer as common public spaces, defined by buildings with particular functions on the one hand, and those with general functions, such as roads and utility lines on the other hand.

Thus, an analysis of the concept of social mix through public spaces in the habitat of the "Frères Fisli" neighbourhood of Azzaba will allow understanding how these spaces are perceived by its inhabitants.

\section{Case study: The "Frères Fisli" neighbourhood}

A hundred years ago, Azzaba city was predominantly rural, made up of natural areas and fields. Today it has become important in relation to the Skikda "Wilaya" (Figure 1), by its spatial and social evolution, as well as by the creation of several types of habitat, which gives it an important urban value.

The "Frères Fisli" neighbourhood taken as a case study is an old space, which occupies an important place in the eastern part of the city. It is surrounded by agricultural land to the north and east and by extensions of individual colonial housing to the south and finally by collective and individual housing to the west. The "Frères Fisli" neighbourhood is composed of collective housing, between social, participatory social and promotional on one side and of individual housing, between the colonial and the subdivision, with an area of $75 \mathrm{Ha}$, a number of 1129 housing units and 5225 inhabitants (Figure 2).

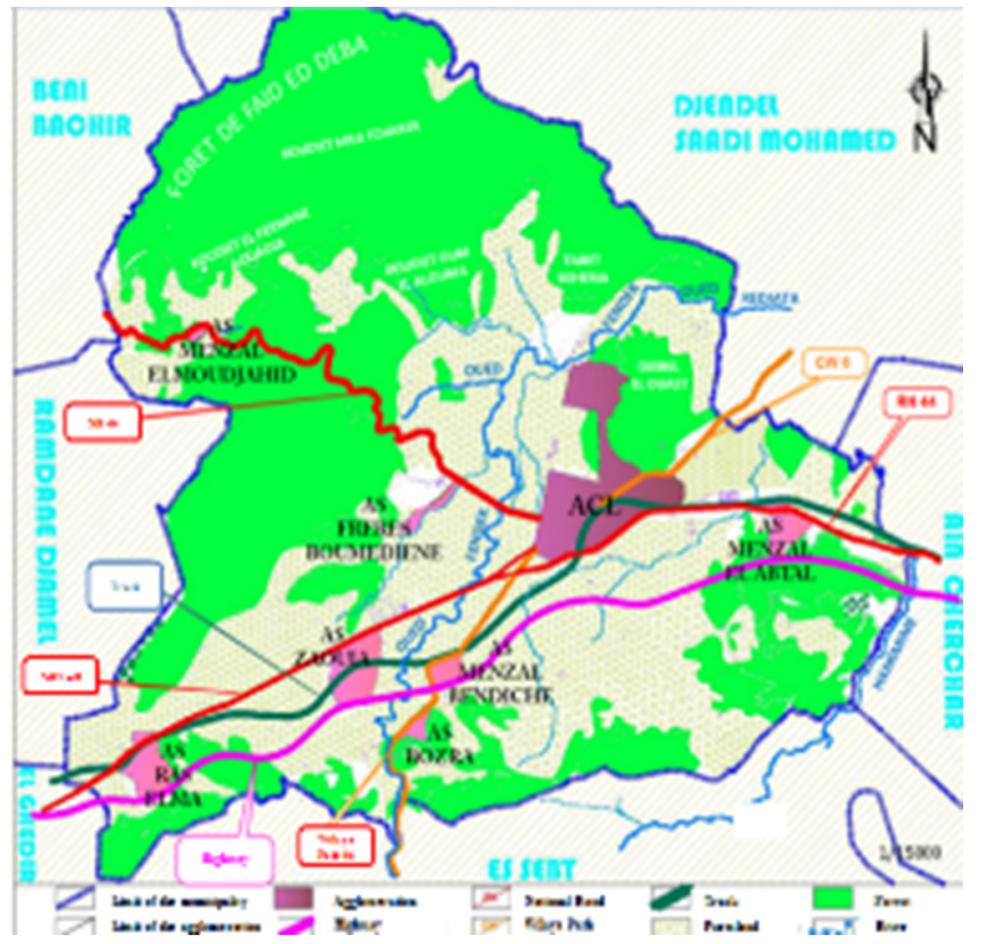

Figure 1: Location of Azzaba city in relation to the Wilaya of Skikda

Source: Plan directeur d'aménagement et d'urbanisme de la commune de Azzaba, 2012, BEM. 


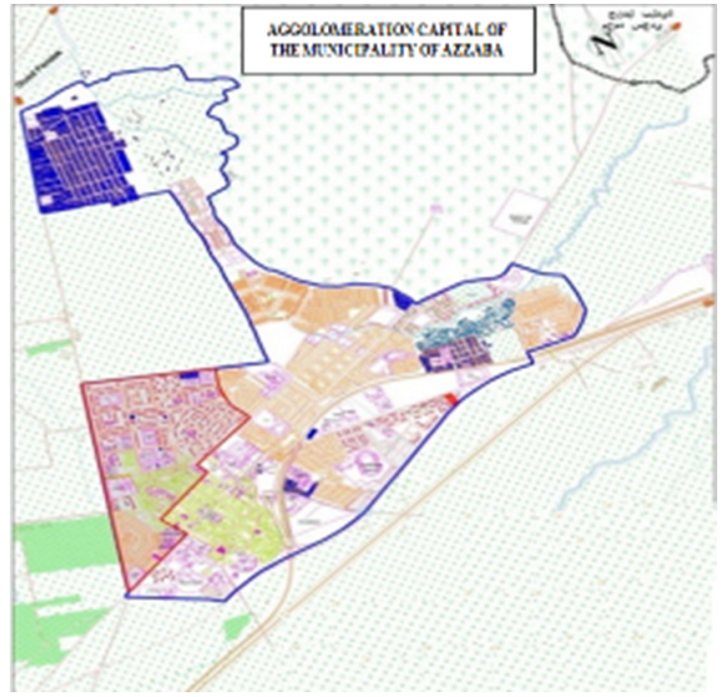

Figure 2: Boundary of the "Frères Fisli" neighbourhood in Azzaba city

Source: Plan directeur d'aménagement et d'urbanisme de la commune de Azzaba, 2012, BEM.

The choice fell on this scale, to expose a case study of a small old Algerian city, by its original inhabitants, to grasp the problem of social mix and thus manage to lean the impact study of participation of the public space in promoting it.

\section{Methodology}

In this research, a methodological study was carried out based on a social and spatial analysis of the study area. It highlights the analysis of a neighbourhood through two investigative tools: the mental map for spatial perception study and the field survey through a closed questionnaire for social and spatial compositions analysis. The results obtained of the analysis are processed using Excel, with a direct link to the spatial font.

\subsection{The Mind Map}

Mind maps show the organization of ideas, which are used to capture the perception of public space by residents in the form of drawings and images that produce sensations by building a powerful link between the individual and his environment. Thus, these maps represent the identifications granted by inhabitants from the places they frequent (Gould \& Rodney, 1974).

With this method, individuals are asked to transform the perceived elements of their spatial environment into images or maps, in the form of drawings. These images will thus produce the organized space that a user has of his city or neighbourhood (CERTU, 1999; Unt.unice.fr, 2017; Bailly, 1877; Lynch, 1960). In this sense, the mental image or map plays an important role in this exercise, because the interviewee must remember the salient elements of a place or a route and translate it into an image or drawing. Thus, a mental map constitutes a reading grid making it possible to identify the use of a space and the adequacy between the way in which the space is fitted out, organized, perceived and used (CERTU, 1999).

The objective of this study makes it possible to measure the knowledge of a place or on the contrary its ignorance and to note the importance given to certain elements of the environment according to concerns, profiles, cultural affiliations, practices, social or individual difficulties. It is a 
relevant tool for revealing notions of neighbourhood boundaries, landmarks, preferred travel routes for example (CERTU, 1999).

In public space analysis, the advantageous use of the mental map is to understand quickly the situation of these spaces, to establish links between the ideas of inhabitants and to know which spaces are audiences most meaningful to them. Some disadvantages of these maps are the encounter of completely empty ones and particularly if the additional question to this image is negative, which in a way does not satisfy survey objective.

\subsection{The on-site survey}

The on-site survey is carried out using a supplementary questionnaire, which complements the information acquired by the mental map, in order to obtain spontaneous answers. The questionnaire is intended to standardize and assist the collection of testimonies from inhabitants, where it is particularly to investigate opinions, attitudes, beliefs, perceptions, experiences or even behaviours. Other information about the interviewees could be known and noted without the need of specific questions. This method makes it possible to reach a larger number of people and achieve better representativeness of the population studied.

The objectives of this survey is to understand how inhabitants of different types of housing in the neighbourhood perceive their public spaces and are well secured, what is the use and function of these spaces, and if living together through these spaces public exists between them. In its accomplishment, we relied on the two concepts of our study: social mix and public space, where three indicators are retained to interpret how social diversity is promoted through public space, namely, the form, the feeling of security and the functions and uses of public spaces.

In this study, a random sample composed of 225 inhabitants chosen out of 5225 is retained, for various characteristics, namely: (age, sex, cultural level, profession, etc.). 98 women and 127 men were interviewed with an age varying between 18 and 70 years, with a significant number having an age between 29 and 30 years (a young and more sensitive population), and a large majority of simple employees, unemployed and retired. The questions, in number of 18 , are specifically linked to our research concepts. The questionnaire was tested beforehand on a small number of inhabitants before its distribution, to check its accessibility to the inhabitants, and to estimate the time taken by the respondents to answer it, which was 45 minutes.

The questionnaire used includes five parts related to the indicators selected above to study these areas:

1. Relations between inhabitants: it allows understanding how inhabitants share life together (ex: Who is the neighbour for you? How often do you have contact with the neighbours?)

2. Perception: composed of questions and areas for drawings (the mental map) which must indicate which space is considered by inhabitant as public in his neighbourhood, with additional questions set out in relation to this map in the event empty (ex: What do you frequent the most in your neighbourhood?

3. The feeling of security: made up of questions that make it possible to check whether the inhabitant is satisfied with these spaces in terms of safety and ease.

4. Functions and uses: to identify their usefulness (ex: Why do you use public spaces in your neighbourhood? What is the function of these spaces?)

5. Some additional questions relating to the expectations of inhabitants.

The questionnaires were delivered and taken from each of the respondents in person. This operation took place between $13^{\text {th }}$ of June and $25^{\text {th }}$ of July 2018 , with several passages to be able to distribute and collect the forms.

\subsection{Social characteristics of the "Frères Fisli" neighbourhood}

The neighbourhood is occupied by a population that is made up of several social categories in the 
different types of existing housing, which allows for a rich study in terms of social mix through public space. Since, inhabitants of the neighbourhood are different in their criteria (socio-professional, level of diploma, origin, sex, age, etc.).

This diversity is marked by socio-professional categories ranging from intermediate professions (simple employees: administrative employees and service personnel) to senior executives (directors of companies, businesses, etc.), as well as workers, traders, and retirees, and finally to the unemployed (Figure 3). Likewise, this diversity is linked to the choice of the type of housing occupied by these inhabitants, according to its cost and characteristics, for example social housing, which is intended for the average social category. Thus, it notes the dominance of simple employees with a percentage of $31 \%$, followed by retirees with $20 \%$, the unemployed and traders with $16 \%$, senior executives with $12 \%$, and finally artisans with $6 \%$ (Figure 3 ).

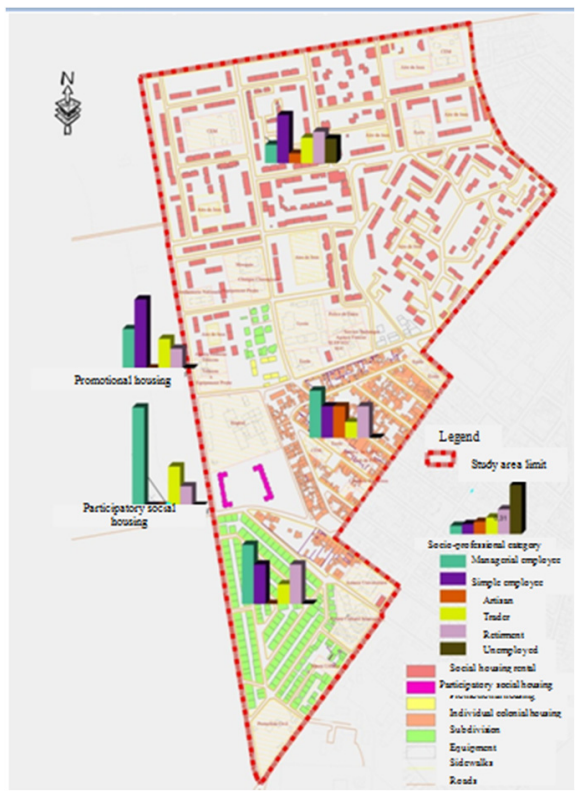

Figure 3: The socio-professional level for inhabitants of the "Frères Fisli" neighbourhood

Diversity in the level of qualifications is discerned with a great representativeness of upper level inhabitants with $32 \%$, followed by those of secondary level, and then those of vocational, middle, and primary training respectively with $19 \%, 14 \%$, and $9 \%$, and finally the illiterate with $6 \%$ (Figure 4 ).

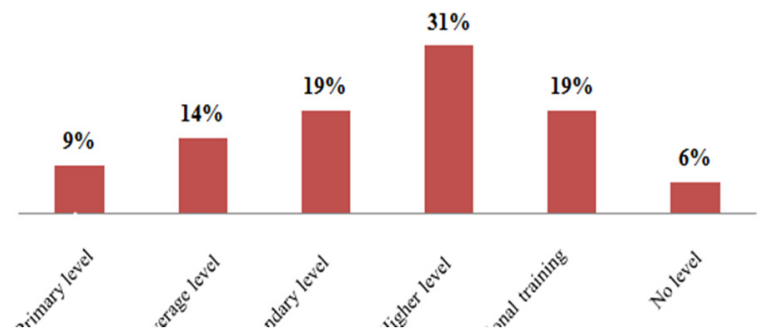

Figure 4: The cultural level for inhabitants of the "Frères Fisli" neighbourhood (in \%) 


\subsection{The spatial study of the "Frères Fisli" neighbourhood}

The neighbourhood includes the built space formed by collective and individual housing, and services, in addition to the non-built space formed by different public spaces (streets, play areas, etc.) (Figure 5). There are a number of 1038 collective dwellings, as well as a number of 91 individual dwellings. As for the services, we differentiate from educational and essential shops located on the ground floor of buildings, and sanitary, cultural, religious and police service, which occupy a large area of the neighbourhood.

The neighbourhood is also composed of several types of inbuilt spaces:

1. Play areas, used as sports fields, as well as marginalized areas used as play areas by children. All of these are accessible to the entire neighbourhood population.

2. Roads: the district is well served by a major road network, through the primary road, as well as by internal secondary and tertiary roads.

3. Car parks: car parks are located all over the neighbourhood.

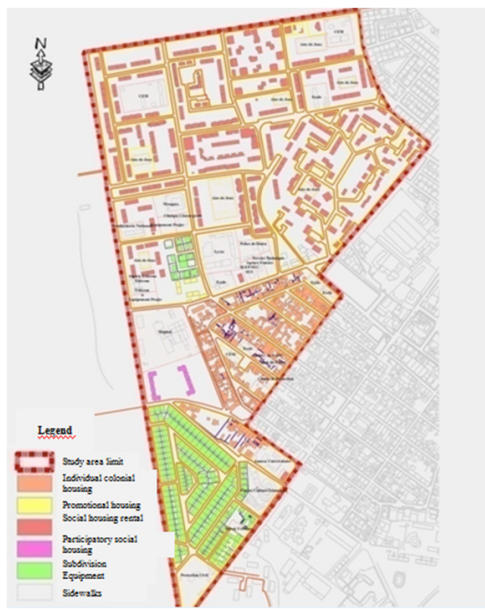

Figure 5: Spatial composition of the "Frères Fisli" neighbourhood

Source: Plan directeur d'aménagement et d'urbanisme de la commune d'Azzaba, 2012, BEM

\section{Social Intermingling for Social Mix through Public Spaces: Results and Discussions}

The analysis carried out using mind maps and questionnaires reveals that the perception of public space by residents does not take into consideration of all spaces that make up the environment. It shows only those that are most meaningful and interesting to them, such as, roads and services, or roads alone, or playgrounds and roads, etc. The representation of mental maps differs from one inhabitant to another, given the large number of parameters, which condition the perception that an inhabitant may have of his space.

The expertise of the three indicators namely; the shape of the public space, the sense of security and the function and use of the latter, effected by reading and analysing the mind maps as well as the questionnaire is exposed in the following sections.

\subsection{Reading by users}

The public space approached by each individual and presented in their mind map indicates one or more spaces that are considered as public spaces, despite the presence of several types in the neighbourhood. 
This reveals a difference in the vision of the occupants in relation to these spaces, as well as in the perception and meaning that inhabitant gives to these spaces. Mind Map Case (Figure 6)

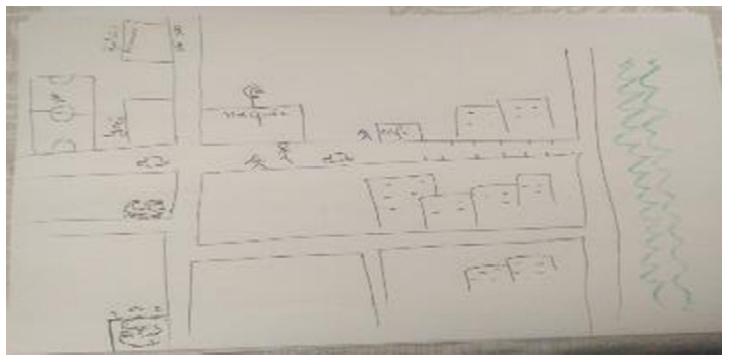

Figure 6: Example of mind map

The inhabitant named "I", active, 30-40 years old, living in the neighbourhood for o8 years Interview report: "I" lives in an apartment building; his balcony overlooks the road and other apartment buildings. He has lived here for 08 years. He chose this accommodation, which is close to his workplace, "it is convenient, I can get there on foot", and as an opportunity, "it is a social housing". He settled for these two reasons and, "little more". His drawing indicates the most significant spaces for him. He regularly goes to the mosque, the café and the premises of the necessities (Bakery, general food...). He always gets there on foot (less time on foot than by car (going there, parking, etc.)). He only uses his car to go to big groceries or for trips. He just feels, "obligated to go there once in a while", to the post office, to the field and to the gym.

Table 1: Different parts of its drawing indicate different activities

\begin{tabular}{|l|l|}
\hline & $\begin{array}{l}\text { "I" finds the neighbourhood "very concrete", "very ugly", and "much closed". } \\
\text { He finds that the buildings are rough with ugly patterns on the facades. }\end{array}$ \\
\hline \hline & $\begin{array}{l}\text { "I" illustrates trash all over the earth as well as in the trash. "It's pretty dirty } \\
\text { overall around here". Which creates a bad smell? }\end{array}$ \\
\hline & $\begin{array}{l}\text { "I" presents spaces mostly frequented by him, which are; the mosque, the café } \\
\text { and the sports field. }\end{array}$ \\
\hline & $\begin{array}{l}\text { "I" reveals a positive point in the neighbourhood, it is the greenery, and the } \\
\text { green colour in the neighbourhood gives a feeling of rest and relief. }\end{array}$ \\
\hline & $\begin{array}{l}\text { "I" shows the presence of groups of people conversing and smoking. They do } \\
\text { not disturb him, "I" feel safe with a strong feeling of belonging to this } \\
\text { neighbourhood is strong in his heart. }\end{array}$ \\
\hline
\end{tabular}

According to "I" the neighbourhood is accessible with is a great family feeling. Before "I" lived in a 
colonial neighbourhood with deteriorated buildings and non-development outdoor spaces, different from the present ones. For him this neighbourhood is a cool place with not too much violence. He replies that, what is good for him are the local services, such as, the post office, the police, educational facilities, being able to do everything on foot and being well installed. However, the rest as regards the quality of public spaces development even if inhabitants frequent them, is not very interesting.

Through the additional responses to these mental maps given by the questionnaire on the shape of public spaces, it is noted that $44 \%$ of respondents make of the street the most frequented public space, followed by play areas with $19 \%$, services with $14 \%$, and workplaces with $6 \%$. As for the $17 \%$ of residents who have not defined the public space of their neighbourhood in the mental map with a total void, 'They use those of the surrounding neighbourhoods, because they see that those in their neighbourhood are in a bad state poor and unorganized (Figure 7).

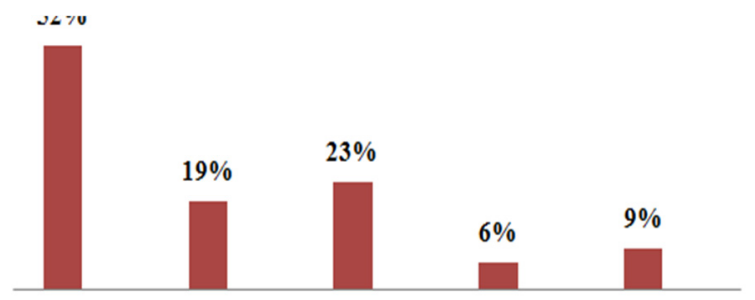

Figure 7: Perception of public spaces according to shape (in \%)

\subsection{Sense of security}

The majority of the inhabitants surveyed consider that their neighbourhood as a safe place, since it represents for them the place of sharing their life and in which they cross each other every day. These reinforces the feeling of belonging to the neighbourhood. $55 \%$ of inhabitants consider the public space, as the space of conviviality, come after $35 \%$ for relaxation and leisure, $7 \%$ frequent them because they are the most preferred for them and $3 \%$ for others (Figure 8 ).

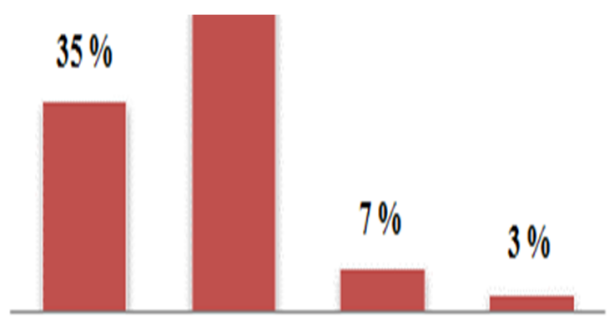

Figure 8: Different uses of the public space (in \%).

However, some important parameters favour this feeling, such as the existing relations between inhabitants. Because, the survey reveals that greetings and conversations exchange always take place between inhabitants of the neighbourhood at street level, services and play areas regardless of the type of housing occupied. Indeed, greetings exchanges between all inhabitants of the neighbourhood in different types of habitat are dominant and are almost often carried out between them, with a percentage of $47 \%$. Conversations that are short or long take place often and sometimes between residents with $26 \%$. Apartment's visits among women are rare with a percentage of $19 \%$. While, there is no contact between $8 \%$ of inhabitants (Figure 9). 
The degree of contact between inhabitants is different. It should be remembered that the seniority in the city of Azzaba as well as the origin of inhabitants always remain as serious points, so that inhabitants remain proud to share moments in the life of together.

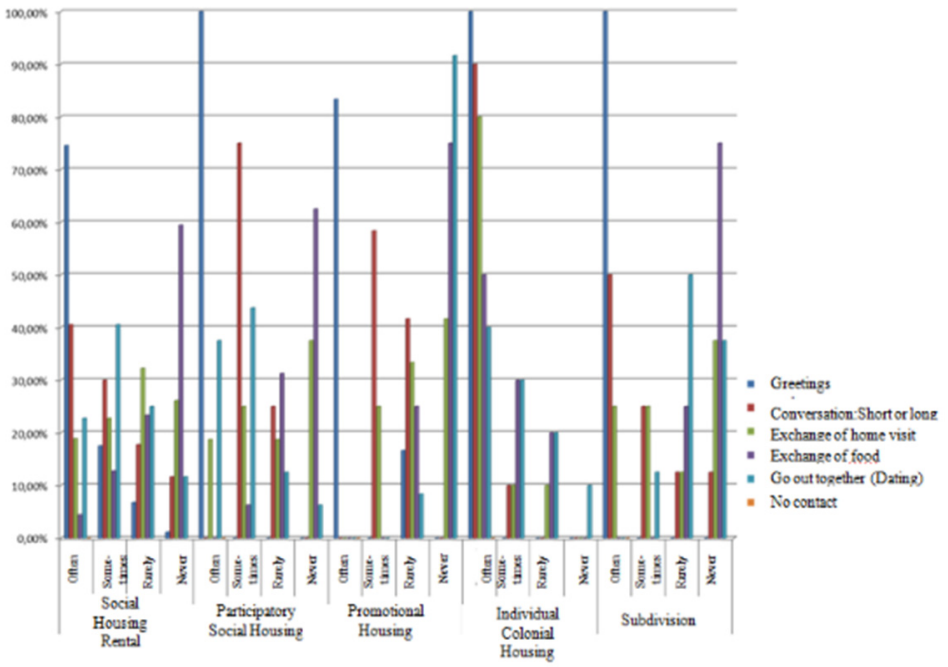

Figure 9: Contact Level between neighbourhood residents (in \%).

\section{$5 \cdot 3$ Function and use}

The use of public space by residents in the neighbourhood is different. Indeed, the majority of inhabitants in different types of habitat make the street as the most frequented space by them every day, come after the play areas and the house which are carried out between often and sometimes. Finally, the other spaces frequentations, such as services and workplaces, this is done in relation to inhabitants' attendance (Figure 10).

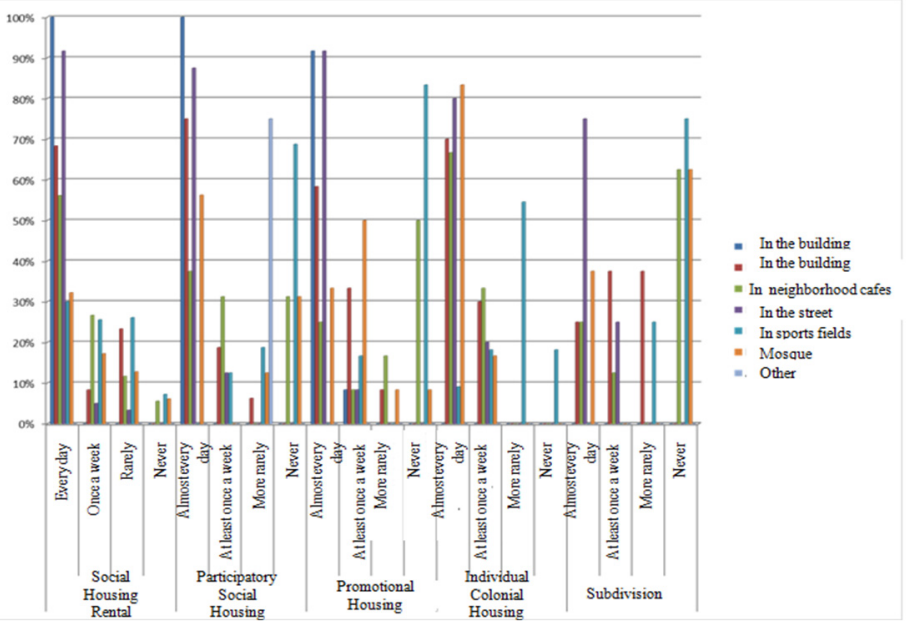

Figure 10: The most frequented public spaces by residents of the neighbourhood (in \%). 
The results of this research have informed residents on the different ways to perceive public space. It also emerges that the street constitutes the most frequented main public space, where the inhabitants intersect the most.

Whatever the use, the feelings of security have been observed; each inhabitant perceives this space as he sees it in his personal use despite the non-adequate arrangement. Public spaces of the "Frères Fisli" neighbourhood represent the spaces that are accessible to the whole public regardless of its social characteristics. They provide the opportunity to connect people of different social categories, to enhance the living together, and to generate opportunities for social interactions for individuals, and therefore to fight against social isolation.

However, it has been shown that the appropriate arrangements of these spaces are necessary for better multiple visits, for strengthening social relations and for controversial living together with a strong feeling of belonging to these spaces (Mazumdar, Learnihan \& all, 2017).

\section{Conclusion}

Organizing a space means allowing individuals to identify themselves and give free progress to the activities they want to practice and make their residential spaces conform to their aspirations. In this context and according to our study, the city of Azzaba presents an active common life among its inhabitants who are native, where their origin represents an important point for the feeling of security and which is important for the life together evolution. Today, Algerian society has evolved towards more diversity and both sexes are constrained to occupy the same space and to receive the same education. Therefore, social class whether poor or rich is not anymore criterion for the occupation and choice of space, which is open to everyone. Thus, the family life has changed a lot.

However, the presence of all these elements as well as the social diversity in the studied neighbourhood, on their own, are insufficient to achieve social mix through existing public spaces, despite their use by inhabitants. Indeed, the presence of several constraints namely, the noncompliance with the predestined use, their abundance by local communities and their non-allocation of functions or planning, weigh down the development of this social mix. In addition, the concept of social mix in this neighbourhood, in particular as well as in the urban structures of Algerian cities, is a concept that is not taken into consideration in the preliminary planning studies by local communities.

In conclusion, public space is a social and cultural place, of use and form, and an important element in the creation and development of social mix. Its presence allows creating a collective social life between inhabitants, whatever the social characteristics (age, sex, cultural level, origin..., etc.).

In our case study, this mix exists in a random and spontaneous way; it is never planned neither programmed, but the life between residents is shared through public spaces despite marginalization in their development. To this end, it is recommended to intervene properly in these public spaces, to revive the city, and strengthen their use, in order to ensure their adequate arrangement, and to express clearly the needs for living together. .

Finally, it is necessary to think carefully about the city with the objective of social mix, by introducing the latter into the planning of neighbourhoods, through laws and regulations.

\section{References}

Baudin, G, 2001. «La mixité sociale : une utopie urbaine et urbanistique, Les utopies de la ville », Revue du crehu, $10,13-23$.

Belmessous, H, 2006. (Mixité sociale, une imposture: retour sur un mythe français), Collection comme un accordéon, Edition la Talande.

Belmessous, F, 2013. « Du seuil de tolérance » à la « Mixité sociale »: répartition et mise à l'écart des immigrés dans l'agglomération Lyonnaise, Revue Belge de géographe, http://journals.openedition.org/belgeo/11540 
Bourdin, S \& Cornier, T, 2017. «Au-delà de la mesure du bien être en milieu urbain, quelle perception de la qualité de vie dans les villes européennes », Ecole de management de Normandie, UMR Idées 6266, in Géographie, Economie Société 19, 3-31

Certu ; 1999, unt. unice. Fr, 2017, Espace public: méthodes pour observer et écouter les usagers, Rapport conçu sous système de management de la qualité certifié BCS

Choay, F \& Merlin P, 1996, Dictionnaire de l'urbanisme et de l'aménagement. Paris: Presses universitaires de France.

Chombant De Lauwe Paul, P.H, 1975, « Paris Essais de sociologie 1952-1964 », Coll. «L'évolution de la vie sociale ».

Cosse, E, 2016. « Projet de loi Egalité et citoyenneté revient à la charge sur la mixité sociale »

Costarelli, I, Kheinhans, R \& Mugnamo, S, 2019, Reframing social mix in affordable housing initiative in Italy and in Netherlands. Closing the gap between discourses Cities, Volume 90, 131-140, https://doi.org/10.1016/j.cities.2019.01.033.

Alves, S. (2019). Nuancing the international debate on social mix: evidence from Copenhagen. Housing Studies https://doi.org/10.108o/o2673037.2018.1556785.

Gerbeau, G, 2015. Mixité sociale, la solution miracle qui cache les vrais enjeux, La Gazette des Communes, 6/2256, 9 février, 8-9.

Gould, P, \&Rodney, W, 1974. Des ouvrages sur les images géographiques : Peter Gould et Rodney White, Mental maps, Travaux de l'Institut de Géographie de Reims .

Gros, J.M \& Thibaud, J.P, 20o1. "Urban space in methods”, Ed. Parenthèses, Marseille.

Hautiere, J, 2011. « Mixité sociale », Travaux de recherche du PUCA.

Hirtt, N \& Delvaux, B. (2017), Peut-on concilier proximité et mixité sociale? Simulation d'une procédure numérique d'affectation des élèves aux écoles primaires bruxelloises, Les cahier de recherche du Girsef, 107, https://cdn.uclouvain.be/groups/cms-editors-girsef/cahier_107_.Hirtt_Delvaux.Final.pdf.

Kerivel, A, \& James, S, 2019.Les enjeux de la mixité sociale en France, Fiches repères, INJEP (Institut national de la jeunesse et de l'éducation populaire), Mars, 42.

Kettaf F, 2015. La fabrique des espaces publics. Conceptions, formes et usages des places d'Oran (Algérie), Les Cahiers d'EMAM[En ligne], $26 \mid 2015$, mis en ligne le 16 juillet 2015. URL: http://journals.openedition.org/emam/995;

Lelevier, C, 20o8. Au nom de la mixité sociale ; les effets paradoxaux des politiques et rénovation urbaine, Savoir, Agir, Editions du croquant, 11-17.

Lelevier, C, 2016. "La mixité sociale : sens et usages dans la politique de la ville, Regards sur la mixité sociale », Achevé d'imprimé en France par imprimerie de Champagne, 52200 Langres, Mars 2018.

Lynch, K, 1960. « Carte mentale et présentations spatiales de résidents », Éditeur Presses universitaires de Rennes http://journals.openedition.org/norois/3343

Mazumdar, S, Learnihan, V, Cochrane, T, Davey, R, 2017, The Built Environment and Social Capital: A Systematic Review. Environment and Behavior. 50(2): 119-158.

Monnet, J, 2012. Ville et loisir : les usages de l'espace public, Historiens E Géographes, 419, juillet-août, $201-213$.

Moles, A \& Rohmer, E, 1973. «Psychologie de l'espace », Revue Tiers Monde, pp. 440-441, Paris.

PDAU, 2012. " Plan Directeur d'aménagement et d'urbanisme de la commune d'Azzaba wilaya de Skikda », BEM.

Nowicka, M, Vertovec, S, 2014.Comparing convivialities: Dreams and realities of living with difference, European journal of cultural studies, 241-356, Volume 17.

Vachon G, Rivard E, 2015.La micro intervention pour comprendre, révéler et faire l'espace public, Inter (120) ; 8-13.

Voisin Bormuth, C, 2019. «Les espaces publics: clef du bien vivre ensemble », Ed la fabrique de la cité, Edito : Instant urbain, 24/o6.

www.lafabriquedelacite.com/publications/les-espaces-publics-clef-du-bien-vivre-ensemble/

Watin M, 2001. Communication et espace public - Univers créoles 1, Anthropos, 266 p, https://doi.org/10.400o/edc.697. 